\title{
Deskripsi Kemampuan Berpikir Tingkat Tinggi Siswa dalam Menyelesaikan Soal Fungsi Kelas X SMAN 2 Tanjungpinang
}

\author{
Syarfina Witri ${ }^{1 *}$, Febrian ${ }^{2}$, Linda Rosmery Tambunan ${ }^{3}$ \\ ${ }^{1,2,3}$ Universitas Maritim Raja Ali Haji, Kota Tanjungpinang, Provinsi Kepulauan Riau 29124, Indonesia
}

Pengiriman: 1 September 2019; Diterima: 23 Oktober 2019; Publikasi: 30 Oktober 2019

DOI: https://doi.org/10.31629/jg.v4i2.1527

\begin{abstract}
Abstrak
Penelitian ini bertujuan untuk mendeskripsikan kemampuan berpikir tingkat tinggi siswa kelas X MIA 2 SMA Negeri 2 Tanjungpinang dalam menyelesaikan soal fungsi. Subjek penelitian sebanyak 40 siswa yang sudah mempelajari materi fungsi terlebih dahulu. Instrumen pengukuran kemampuan berpikir tingkat tinggi siswa terdiri dari 10 soal berupa soal uraian. Data dianalisis dengan menggunakan metode rata-rata sebagai penjelasan kemampuan berpikir tingkat tinggi siswa. Kemampuan berpikir tingkat tinggi siswa ditinjau dari indikator kemampuan berpikir tingkat tinggi yaitu menganalisis, mengevaluasi dan mencipta. Hasil penelitian yang didapat adalah pada indikator menganalisis rata-rata yang diperoleh adalah 47,85 dengan kategori cukup, indikator mengevaluasi dengan rata-rata 12,50 kategori sangat kurang. Dan indikator mencipta dengan rata-rata 19,02 dengan kategori sangat kurang.
\end{abstract}

Kata kunci: deskripsi; kemampuan berpikir tingkat tinggi

\begin{abstract}
This study aims to describe the thinking ability of class X MIA 2 of SMA Negeri 2 Tanjungpinang in solving functional problems. Research subjects are a total of 40 students who have received material of function before. Instrument for the assessment of students' higher-order thinking skills consisted of 10 questions. Data were analyzed using the average method as an explanation of students' higher-order thinking skills. Considering the high level of students in terms of high-level thinking ability indicators, namely analyzing, evaluating and creating. The results obtained on the average analyzing indicator obtained is 47.85 with enough category, the indicator of evaluating with an average of 12.50 with very less categories. And the indicator of creating with an average of 19.02 with very less category.
\end{abstract}

Keywords: description; higher order thinking skill

\section{Pendahuluan}

Pendidikan adalah usaha pendewasaan manusia seutuhnya untuk mengembangkan kualitas diri menuju terbentuknya kepribadian melalui pengajaran dan pelatihan. Pendidikan sangat penting bagi masyarakat sejak dini. Seiring perkembangan zaman yaitu berkembangnya ilmu pengetahuan dan teknologi seperti sekarang, diperlukan sumber manusia matang yang memiliki pemikiran kritis, kreatif, dan inovatif. Sumber manusia seperti itulah yang mampu memanfaatkan teknologi, sehingga informasi yang diperoleh dapat diolah menjadi suatu yang berguna untuk 


\section{JURNAL GANTANG. Oktober 2019; IV(2): 155 - 160 \\ p-ISSN. 2503-0671 \\ e-ISSN. 2548-5547}

kehidupan manusia.

Untuk membangun sumber daya manusia yang matang, tentu membutuhkan pendidikan agar informasi yang diperoleh dapat diolah dengan teknologi yang ada. Untuk meningkatkan sumber daya manusia yang paling penting adalah dengan mempelajari pelajaran matematika. Hal ini terlihat dari kurikulum nasional bahwa matematika bertujuan untuk mengembangkan kemampuan peserta didik dalam mengukur, menghitung, menurunkan, dan mampu mengaitkan rumus matematika dengan kehidupan sehari-hari. Serta peserta didik mampu menyelesaikan permasalahn dengan menggunakan solusi yang tepat.

Berdasarkan hasil tes dari survey Programme for International Student Assesment (PISA) menunjukkan bahwa kemampuan matematika peserta didik di Indonesia masih rendah. Indonesia berada pada peringkat 63 dari 70 negara pada tahun 2015 . Peserta didik Indonesia merasa sulit untuk menyelesaikan tes yang diberikan. Karena, peserta didik belum terbiasa menggunakan kemampuan berpikir tingkat tinggi dalam menyelesaikan soal.

Menurut Noer (2010) kemampuan berpikir tingkat tinggi sangat diperlukan dalam pembelajaran untuk memecahkan masalah yang dihadapi dalam kehidupan. Sedangkan menurut Direktorat Pembinaan SMA kemampuan berpikir tingkat tinggi dapat mendorong siswa untuk berpikir lebih mendalam dan luas tentang materi pelajaran. Sehingga, Kemampuan berpikir tingkat tinggi atau HOTS adalah berpikir yang lebih kompleks untuk menemukan solusi dari suatu permasalahan.

Soal-soal tipe HOTS mengukur kemampuan siswa pada level menganalisis, mengevaluasi, dan mencipta. Sehingga dalam mengerjakan soal HOTS harus mampu melibatkan kemampuan analitis dan bernalarnya dalam memecahkan masalah sehari-hari. Hal ini ditinjau dari taksonomi Bloom yang telah direvisi dalam Anderson \&

Krathwohl (2015) meliputi, menganalisis (C4), mengevaluasi (C5), dan mencipta (C6).

Sebelum melakukan penelitian ini, telah banyak penelitian yang mendeskripsikan kemampuan beripikir tingkat tinggi siswa, diantaranya penelitian yang dilakukan oleh Wicasari (2016) yang menggali kemampuan berpikir tingkat tinggi siswa dalam memecahkan masalah. Tujuan dari penelitian yang dilakukan adalah untuk mengetahui sejauh mana kemampuan peserta didik ditinjau dari tahapan taksonomi Bloom yaitu remembering, understanding, applying, analysing, and creating. Adapun hasil dari penelitian ini didapatkan bahwa secara umum peserta didik belum ada yang mampu mencapai tahapan creating. Adapun perbedaan dengan penelitian yang akan dilakukan adalah pada penelitian sebelumnya yang dianalisis adalah tahapan kemampuan berpikir tingkat tinggi ditinjau dari taksonomi Bloom. Sedangkan penelitian yang akan dilakukan adalah kemampuan berpikir tingkat tinggi siswa dilihat setiap indikator kemampuan berpikir tingkat tinggi sesuai dengan taksonomi Bloom revisi.

Kedua, penelitian yang dilakukan oleh Irawati (2018) yang bertujuan untuk mengetahui tingkat kemampuan berpikir tingkat tinggi. Tujuan dari penelitian yang dilakukan oleh Irawati adalah untuk mengetahui kemampuan berpikir tingkat tinggi siswa dalam menyelesaikan soal pemecahan masalah pada materi bilangan bulat. Ketiga, penelitian oleh Ramdhan et al. (2018) yang bertujuan untuk menganalisis instrumen dan profil kemampuan berpikir tingkat tinggi.

Berdasarkan ketiga penelitian yang dilakukan hasil yang diperoleh secara keseluruhan adalah kemampuan berpikir tingkat tinggi siswa dalam menyelesaikan soal masih kurang. Kelebihan dari penelitianpenelitan sebelumnya adalah peneliti mampu menentukan kemampuan berpikir tingkat tinggi siswa secara keseluruhan. Kekurangan dari penelitian sebelumnya adalah peneliti 
belum mendeskripsikan kemampuan berpikir tingkat tinggi siswa pada setiap indikator kemampuan berpikir tingkat tinggi. Sehingga, perlu dilakukan penelitian yang lebih rinci lagi dalam meneliti kemampuan berpikir tingkat tinggi siswa pada setiap indikator berpikir tingkat tinggi. Selanjutnya pembiasaan pemberian soal yang berorientasi HOTS agar siswa terlatih dan dapat meningkatkan kemampuan berpikir tingkat tingginya.

Oleh karena itu, peneliti tertarik melakukan penelitian untuk mengetahui kemampuan berpikir tingkat tingkat siswa dan perlu dilakukan pengkajian lebih dalam. Rumusan masalah penelitian ini adalah bagaimana kemampuan berpikir tingkat tinggi siswa dalam menyelesaikan soal fungsi. Tujuan penelitian ini untuk mendeskripsikan kemampuan berpikir tingkat tinggi siswa pada materi fungsi.

\section{Metode Penelitian}

Penelitian ini merupakan penelitian deskriptif kuantitatif yang dilaksanakan di SMA Negeri 2 Tanjungpinang dengan subjek penelitian adalah siswa kelas X MIA 2 yang berjumlah 40 siswa yang sudah mempelajari materi fungsi. Menurut teori Jean Piaget seseorang yang telah berumur 11-18 tahun masuk pada tahap operasional formal artinya pada tahap ini seseorang sudah mampu berpikir abstrak dan logis dan menggunakan pola pikir kemungkinan (Lestari \& Yudhanegara, 2017). Sehingga siswa kelas $\mathrm{X}$ cocok menjadi subjek dalam penelitian ini. Peneliti memberikan 10 butir soal uraian yang telah disusun dengan menggunakan indikator berpikir tingkat tinggi. Melalui metode ini peneliti memaparkan dan menganalisis secara detail mengenai kemampuan tingkat tinggi siswa dalam menyelesaikan soal fungsi.

Penelitian ini dilakukan dalam 3 tahap, antara lain: 1) Tahap persiapan meliputi kegiatan penyusunan instrumen. 2) Tahap pelaksanaan yaitu, peneliti melakukan kegiatan pengambilan data yang dilaksanakan pada bulan Mei 2019. 3) Tahap penyelesaian dilakukan pengolahan data
Instrumen yang digunakan dalam penelitian ini adalah peneliti sendiri sebagai instrumen utama dan instrumen pendukung berupa soal tes. Lembar tes yang yang diujikan divalidasi oleh ahli memuat materi, konstruk dan bahasa. Soal yang diujikan telah diuji kevalidannya. Sehingga lembar soal dapat digunakan dalam penelitian. Analisis data dilakukan dengan menggunakan metode deskripsi rata-rata sebagai penjelasan hasil tes siswa berdasarkan indikator kemampuan berpikir tingkat tinggi.

\section{Hasil dan Pembahasan}

Sebelum melakukan penelitian peneliti mempersiapkan instrumen yang akan digunakan untuk penelitian. Pertama adalah menyusun kisi-kisi soal yang disesuaikan dengan indikator berpikir tingkat tinggi mengacu pada kompetensi dasar dan indikator pencapaian kompetensi pada materi fungsi.

Berdasarkan Kompetensi Dasar dan Indikator Pencapaian Kompetensi peneliti menyusun kisi-kisi soal dengan indikator berpikir tingkat tinggi pada topik fungsi. Pada indikator menganalisis (C4) ada 5 soal yaitu soal nomor 1, 2, 3, 6 dan 8. Indikator mengevaluasi (C5) ada 1 soal yaitu soal nomor 9. Indikator mencipta (C6) ada 4 soal yaitu soal nomor 4, 5, 7, dan 10 .

Setelah menyusun soal dilakukan uji validasi. Uji validasi dilakukan dengan memberikan lembar validasi. Adapun yang menjadi validator dalam penelitian ini adalah dosen matematika dan guru matematika. Uji validasi yang dilakukan didasarkan pada materi, konstruk dan bahasa. Berikut hasil rekap validasi oleh ahli yang dianalisis menggunakan angka indeks.

Berdasarkan analisis angka indeks yang dilakukan soal yang telah divalidasi memiliki kategori baik. Baik dilihat dari aspek materi, konstruk, dan bahasa. Berdasarkan hasil analisis tersebut soal yang dibuat sudah bisa digunakan dalam penelitian dengan melakukan revisi terlebih dahulu berdasarkan saran dan komentar yang diberikan oleh validator.

Selanjutnya adalah pengujian soal terhadap subjek penelitian. Data hasil tes 
JURNAL GANTANG. Oktober 2019; IV(2): 155 - 160

p-ISSN. 2503-0671

e-ISSN. 2548-5547

dianalisis untuk menentukan skor rata-rata akhir pada setiap indikator. Kategori kemampuan berpikir tingkat tinggi siswa adalah sebagai berikut.

Tabel 1. Kategori kemampuan berpikir tingkat tinggi

\begin{tabular}{cc}
\hline Nilai & Kategori \\
\hline $81-100$ & Sangat baik \\
\hline $61-80$ & Baik \\
\hline $41-60$ & Cukup \\
\hline $21-40$ & Kurang \\
\hline $0-20$ & Sangat kurang \\
\hline
\end{tabular}

Penelitian ini mendeskripsikan kemampuan berpikir tingkat tinggi siswa kelas $\mathrm{X}$ MIA 2 dalam menyelesaikan soal fungsi. Kemampuan berpikir tingkat tinggi dari subjek penelitian diamati oleh melalui hasil tes kemampuan berpikir tingkat tinggi. Dasar untuk mengetahui kemampuan siswa adalah dengan melihat data skor hasil tes disetiap indikator. Analisis rata-rata menggunakan rumus:

$$
\bar{x}=\frac{\sum n}{N}
$$

Keterangan:

$\bar{x}=$ nilai rata-rata

$\sum n=$ jumlah skor keseluruhan

$\mathrm{N}=$ banyaknya siswa

Berdasarkan hasil analisis rata-rata yang dilakukan kemampuan berpikir tingkat tinggi siswa pada setiap indikator adalah sebagai berikut.

Tabel 2. Hasil rata-rata

\begin{tabular}{lll}
\hline Indikator & Rata-rata & kategori \\
\hline Menganalisis & 47,85 & Cukup \\
\hline Mengevaluasi & 12,50 & Sangat kurang \\
\hline Mencipta & 19,02 & Sangat kurang \\
\hline
\end{tabular}

Soal materi fungsi menggunakan indikator kemampuan berpikir tingkat tinggi yaitu menganalisis (C4), mengevaluasi (C5), dan mencipta (C6). Pada tabel di atas dapat dilihat bahwa kemampuan berpikir tingkat tinggi siswa pada indikator menganalisis cukup, indikator mengevaluasi sangat kurang dan indikator mencipta sangat kurang. Jika dirataratakan secara keseluruhan kemampuan berpikir

tingkat tinggi siswa dengan rata-rata 26,45 dikategorikan kurang.

Pada soal dengan indikator menganalisis siswa sudah mampu menganalisis soal dengan kategori cukup. Pada indikator menganalisis soal nomor 1 dengan skor total 5 . Ada 26 siswa yang memperoleh skor maksimal tetapi ada 8 siswa yang sama sekali tidak memiliki skor. Pada soal nomor satu umumnya siswa mampu menganalisis soal yang diberikan dengan baik. Hanya saja ada siswa yang tidak mendapat skor sama sekali karena ada yang tidak mengerjakan, ada yang tidak paham dengan instruksi soal. Hal ini sesuai dengan teori yang dikemukakan oleh Anderson \& Krathwohl (2015) menjelaskan bahwa menganalisis adalah melibatkan proses memecah-mecah materi menjadi menjadi bagian-bagian kecil dan menentukan bagaimana hubungan antar bagian dan struktur keseluruhannya. Berdasarkan teori ini secara umum siswa mampu untuk menganalisis permasalahan yang diberikan.

Indikator menganalisis pada soal nomor 2 memiliki skor maksimum 7. Ada 11 siswa yang mampu menjawab soal dengan baik dan ada 21 siswa yang sama sekali tidak memiliki skor. Sedangkan siswa yang lain mendapat skor diantaranya. Pada soal nomor 2 siswa sudah mulai bingung mengerjakan soal karena banyaknya yang diketahui oleh soal dan pertanyaan pada soal nomor 2 belum pernah dijumpai pada saat pembelajaran. Pada soal nomor 3 ada 16 siswa yang memperoleh skor tertinggi dan ada 16 siswa yang sama sekali tidak memiliki skor. Pada soal nomor 4 tidak ada satupun siswa yang mampu memperoleh skor tertinggi, serta 25 siswa tidak memperoleh skor sama sekali. Pada soal ini siswa tidak mampu memecah-mecah yang diketahui dalam soal sehingga tidak mampu untuk menyelesaikan soal tersebut. Sedangkan ada yang sama sekali tidak mendapatkan skor karena tidak menjawab dan ada beberapa siswa yang menjawab tidak relevan dengan permintaan soal dan jawaban yang diberikan tidak sesuai dengan kunci jawaban. 
Indikator menganalisis yang terakhir adalah pada soal nomor 5. Pada soal ini ada 5 siswa yang memperoleh skor tertinggi dan ada 24 siswa yang mendapat skor 0 . Pada indikator menganalisis kabanyakan siswa tidak mampu menganalisis soal nomor 5. Dibuktikan bahwa pada soal nomor 5 banyak siswa yang memperoleh skor 0 .

Sehingga, secara keseluruhan pada indikator soal menganalisis hanya beberapa siswa yang mampu menganalisis soal. Serta banyak siswa yang tidak mampu menganalisis soal dengan baik. Oleh karena itu pada indikator menganalisis kemampuan berpikir tingkat tinggi siswa dikategorikan cukup.

Sementara itu, pada indikator soal mengevaluasi yaitu soal nomor 9 siswa diminta untuk menentukan kesimpulan akhir dari grafik yang diberikan terkait daerah asal, daerah hasil dan rumus fungsi. Pada soal nomor 9 tidak ada satupun siswa yang dapat skor maksimal. Skor maksimal pada soal nomor 9 adalah 3 . Sedangkan skor yang yang diperoleh siswa adalah 1 dan 0 . Pada soal ini siswa belum mampu untuk membaca grafik yang diberikan sehingga susah untuk menjawab soal yang diberikan. Jawaban yang diberikan seragam yaitu hanya menjawab daerah asal dan daerah hasil. Tetapi untuk menentukan daerah asal dan daerah hasil secara umum tidak ada siswa yang bisa. Menurut Anderson \& Krathwohl, (2015) mengevaluasi adalah membuat keputusan berdasarkan kriteria dan standar. Sehingga, dapat disimpulkan bahwa pada indikator soal mengevaluasi siswa belum mampu untuk membuat keputusan berdasarkan kriteriakritaria yang telah dirumuskan dalam soal. Pada indikator ini kemampuan berpikir tingkat tinggi siswa dikategorikan sangat kurang.

Indikator soal mencipta adalah pada soal nomor 4, 5, 7, dan 10. Pada soal mencipta siswa diminta untuk membuat model matematika dan model secara umum. Dari soal nomor 4 kebanyakan siswa sudah mampu membuat model matematika yang diminta. Pada soal nomor 4 ada 19 siswa yang memperoleh skor maksimum. Pada soal nomor 5 kemampuan berpikir tingkat tinggi siswa dikategorikan kurang. Artinya siswa kurang paham dengan soal yang diberikan. Pada soal nomor 7 dan 10 adalah membuat model matematika berdasarkan ilustrasi yang diberikan. Pada soal ini tidak ada satupun siswa yang mendapat skor maksimum. Menururt Anderson \& Krathwohl (2015) mencipta adalah proses menyusun elemen-elemen menjadi sebuah keseluhan yang fungsional dan koheren. Berdasarkan teori yang dikemukakan pada indikator mencipta siswa belum mampu untuk menyusun elemen-elemen yang diketahui untuk membuat model secara umum yang memenuhi untuk semua kemungkinan. Sehingga, pada indikator soal mencipta kategori berpikir tingkat tinggi yang diperoleh adalah sangat kurang.

Berdasarkan hasil rata-rata siswa pada tiap indikator kemampuan berpikir tingkat tinggi. Didapatkan bahwa pada indikator menganalisis lebih tinggi dari dua indikator kemampuan berpikir tingkat tinggi lainnya yaitu 47,85 dengan kategori cukup. Sedangkan pada indikator mengevaluasi rata-rata yang diperoleh adalah 12,50 dengan kategori kemampuan berpikir tingkat tinggi sangat kurang. Sedangkan indikator mencipta rata-rata yang diperoleh adalah 19,02 dengan kategori sangat kurang. Rendahnya rata-rata yang didapat karena siswa mengalami kesulitan dalam menyelesaikan soal yang diberikan.

\section{Kesimpulan}

Adapun kesimpulan dari penelitian yang dilakukan adalah siswa kelas X MIA 2 SMA Negeri 2 Tanjungpinang bahwa kemampuan berpikir tingkat tinggi siswa pada indikator menganalisis pada kategori cukup, indikator mengevaluasi dengan kategori sangat kurang dan pada indikator mencipta kemampuan berpikir tingat tinggi siswa pada kategori sangat kurang. Sehingga, dari kesimpulan yang didapat bahwa siswa harus lebih dibiasakan lagi membahas soal-soal berkemampuan tingkat tinggi. Karena, kemampuan berpikir tingkat tinggi masih cukup dan sangat kurang difokuskan jika ditinjau dari indikator soal kemampuan berpikir tingkat tinggi. 
JURNAL GANTANG. Oktober 2019; IV(2): 155 - 160

p-ISSN. 2503-0671

e-ISSN. 2548-5547

\section{Referensi}

Anderson, L. W., \& Krathwohl, D. R. (2015). Pembelajaran, pengajaran, dan asesmen. Yogyakarta: Pustaka Belajar.

Irawati, T. N. (2018). Analisis kemampuan berpikir tingkat tinggi siswa SMP dalam menyelesaikan soal pemecahan masalah matematika pada materi bilangan bulat. Jurnal Gammat, 3(2), $1-7$.

Lestari, K. E., \& Yudhanegara, M. R. (2017). Penelitian pendidikan matematika. Bandung: Refika Aditama.

Noer, N. (2010). Peningkatan berpikir kritis, kreatif, reflektif (K2R) matematis siswa SMP melalui pembelajaran berbasis masalah. Bandung: FMIPA UPI.

Ramdhan, G., Dwinajananti, P., \& Wahyuni, S. (2018). Analisis kemampuan berpikir tingkat tinggi (higher order thinking skill) menggunakan instrumen two tier multiple choice materi konsep dan fenomena kuantum siswa SMA di kabupaten Cilacap. Physic Education Journal, 7(3), 85-90.

Wicasari, B. (2016). Analisis kemampuan berpikir tingkat tinggi siswa dalam menyelesaikan permasalahan matematika yang berorientasi pada HOTS. Progsiding Seminar Nasional Reforming Pedagogy. 